"Vox Patrum"6/1986/ z. 11

\title{
OPRACOWANIA PATRYSTYCZNE Z XIX WIEKU NA WYDZIALE TEOLOGICZNYM WE WROCŁAWIU
}

W Bibliotece Kapitulnej we Wrocławiu zachowało się pięc rękopisów o tematyce patrystycznej, które zostały opracowane przez studentów Wydziału Teologieznego wXIX w. Jako "prace konkursowe" /Preisarbeit, Pre1sausgabe/: jedna z nich zaginęła podczas drugiej wojny śriatorej, a pozostałe cztery dotycza przede wszystkim eklezjolog11.

Historia Kościoła na Wydziale Teologicznym we Frocławiu zajmowall sie $\mathrm{XIX}$ W. 1 W 1. poł. XX.w. następujacy profesorowie: ks. Marcin Pełka latach 1811-1823, ks. Karol Ignacy Herber 18141831, ks. Józef Ignacy Ritter 1830-1856, ks. Józef Hubert Reinkens 1857-1870, ks. Hugo Laemmer 1873-1897, ks. Max Sdralek 1896-1913, ks. August Nturnberger 1901-1910, ks. Józef Wittig 1911-1925, ks." Franciszek Ksawery Seppelt 1915-1945, ks. Franciszek Józef Dolger 1926-1929, ks. Bertold Altaner 1929-1933, ks. Feliks Haase 1924$1045^{1}$. Niektórzy $z$ nich interesovali siz téz patrologiz.

We wrocławskim środowisku universyteckin już na przełomie XVIII 1 XIX w. rozwinzł dość ożywiona 1 bogatą patrystyczna dziazalność naukora ks. Marcín $P$ e $\mathbf{z}$ a, który wykładał ponadto historizz kościoła 1 prawo oraz szereg innych przedmiotów, jak Język polski, literaturę, encyklopedį teologiczną $i$ teologię dogmatyczną. Był on synem wsi śląskioj 1 znał dobrze język polski. Urodził sie 4 listopada 1757 r. "Broźcu koło Prudnika jako syn Jerzezo 1 Marian-

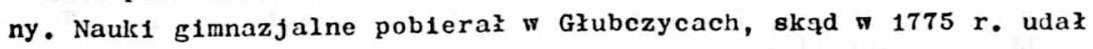
sie na Universytet Wrocłarski, nastapnie do Wiednia 1 ponownie do Wrocławia. Swięcenta kapłańskie otrzymał 22 grudnia 1781 r., do-

1 E.Kleineidam, Die katholisch-theologische Fakultat der Universitat Breslau 1811-1945, Koln 1961, 22-23. 
ktorat z teologi1 30 sierpnia 1782 r., a stanowisko profesora 1 lozofii na Untwersytec1e Wrocławskim $w 1786$ r. Katedre profesorska opuścil dopiero w 1823 r., kiedy obdarzono go godnościa prałata scholastyka. Podczas wykładów patrologil trzymał sie podrecznika Stefana Wiesta, "Institutiones Patrologiae in usum academicum" /Ingolstadt 1795/, którego sposób wyłozenia materiału 1 zasady dydaktyczne miały być "quam maxime utiles"2. Zmarł 5 czerwca 1828 r. Juz Wilhelm von Humbolt, autor projektu organizacjl Enfwersytetu w Berlinie, mawial w 1811 r., ze decydujacym czynnikiem przy kazdej reformie uniwersyteckiej jest znalezienie waściwych profesorów. Przekonanie to rzutowało równiez niewątplimie na Wydziaz Teologiczny we Wrocławiu. Schyłek bowlem XIX w., dz1ek1 wysiłkom ksiedza kardynała Jerzego Koppa, przyníss znaczne odmłodzenie 1 odnowienie Vydziału Teologicznego tym mieście, gdzie pojawiły się nowe siły także na odcinku patrologi1.

Nalezał do nich najpierw ks.Józer W 1 t 1 g.Urodzony $w$ Słupcu koło Nowej Rudy 22 sierpnia 1879 r., habilitowany 3 listopada 1909 r. z historil Kościoła starożytnego, wykładał na Wydziale historię sztuki 1 patrologię. Późniejsze drogi jego zycia nieco się powikłały, ale zostały zakończone szczęśliwą konwersją. Zmarł 22 s1erpnia 1949 r. Gobrde rejonte Laneburga ${ }^{3}$.

Sławe czoł̣owego patrologa o rozgłosie europejakim zdobyz. we Wrocławiu ks. Bertold A 1 t a $e r$, urodzony na Górze éw. Anny 10 mrześnia 1885 r., habilitowany 24 pazdzlernika 1919 r. z histori1 średniowiecznej 1 nowozytnej, przyjaz w $1925 \mathrm{r}$. wykłady po ks. Józefie Wittigu, stając slę od 1929 r. zwyczajnym profesorem historil Kościoła 1 patrologil na Fydzlale. Tutaj przerobil on naj-

2 Por. W.Urban, Ks. Marcin Pełka - śląsk1 kanonista /1757-1828/, PK 14/1971/325-329; Leopold hr. Sedlnicki ksiaze-biskup wrocłarsk1/1836-1840/na tle dziejów Kościoła na Śląsku w pierwszej połowie XIX $w_{.}$, Warszawa 1955, 40; F.Haase, Festschrift zur Hundertjahrfeier der Universitat Breslau. Die Schriftstellerische Tutigkeit der Breslauer Theologischen Fakultaten von 1811 bis 1911, Breslau 1911 87-88; E.Kleineidam, Die katholisch-theologische Fakultat der Universitat Breslau 1811-1945, 22-23.

3 A.Marcol, Józef Wittig 1879-1949. Spojrzenie po trzydziestu latach, "Studia Teologiczno-Historyczne Slaska Opolskiego" T/1979/ 295-318; W.Urban, W sprawie konwersj1 ks. Józefa Wittiga, HD 33/1964/ 107-112. 
p1erw "Patrologiq" G.Rauschena, która wydał w $1931 r_{\bullet}$ w 1011 edycj1, a nastepnie w $1931 \mathrm{r}$. opublikował "Patrologię" we własnym opracowaniu. Wkrótce jednak, bo juź w 1933 r. utracił swa uniwersytecka katedrę z powodu przynalezności do Ligi pokoju katolikón niemieckich. Rozpoczął wóticzas pracę jako wikariusz przy katedrze wrocłansklej. Wobec zblizającego sie oblęzenia Wrocławia w 1945 r. opuścil to miasto 1 od 14 listopada 1945 r. zostal zwyczajnym profesorem patrologil 1 liturgiki na Uniwersytecle w Warzburgu: By to niewatpliwie najwybitniejszy patrolog wrockawskiego Fakultetu Teologicznego o światowym rozgłosie 4 .

Wspomniane wyzej konkursowe opracowania patrystyczne z XIX $⿴$. na Tydziale, pochodza z róznych lat.

Jako plerwszą nalezy wymienié rozprawe pt. "An in Ecclesia Christi unitas absque centro unitatis servari possit et num aliud unitatis centrum designare liceat praeter Homanum Pontificem, 1egitimum beati Petri Apostolorum principis successorem"? Praca pisana W Jezyku lacińsk1m, liczy 113 stron oraz posiada uwage: "Pre1sarbeit der Theologischen Fakultat in Breslau 1820". Do zbiorów B1blloteki Kapitulnej we Wrocławiu przekazał Ja w 1924 r. ks. profesor Bertold Altaner, gdzie w dziale rękopisów została wpisana pod sygnatura 403. Jej autor roztrzassa problem "de unitate Ecclesiaen 1 "de statuto unitatis centro", stwierdzajac wo wniosku, ze "Romanus pontifex est legitimus beati Petri successor" oraz "Romanae cathedrae primatus ab ecclesia catholica semper agnitus fuit". Zakończenie pracy pełne jest triumfalnej wizji o Kościele: "Quae omnia quum fluxa vanaque sint - Petra Petri sola 1mmortalisl Longa ruebant saecula, ruentque placide, dummodo - se ipsam cognoscere et non esse velit, nisi centrum unitatis, lumen orbis, vinculum charitatis! Quae utinam semper futura sit, precamur - moxque iterum erit: unus grex et pastor unus I

Nastepna praca konkursowa o sygnaturzo 407, p1sana w $1840 \mathrm{r}$. równiez w języku łacińskim, l1czy 436 stron 1 nosi tytuł: "De Essenorum ot Therapeutarum origine et doctrina". Rozwija ona tematyke z zakresu historil sekt. Esseniczycy, porstali na początku II w. przed Chrystusem jako "reakcja przeciwko postępującej hellenizacji zy-

4 B.Klelnoldam, dz.cyt. 125: "fuhrender Patrologe von Weltruf". 
dbw palestyriskich", tworzyli zdaniem autora grupę zamknięta, odznaczająca sį surowym 1 ascetycznym charakterem, zyjąca zo nspólnej pracy 1 majątku oraz w dozgonnym bezzeństwie. Podzielali oni przekonania monoteistyczne ${ }^{5}$. Autor rozwija między innymi w swej pracy zdanie Owidiusza: "Ut desint vires, tamen est laudanda voluntas". Dalsze dwie rozprawy dotycza eklezjologil 1 hierarchi1 u \&́w. Cypriana.

Autorem pierwszej noszacej sygnature 570 oraz 11 czącej 22 karty napisanej $1841 \mathrm{r}$. po lacinie pracy konkursowej pt. "Doctrina S.Cypriani de Sedis Romanae primatu proposita atque exposita, quaeritur: utrum oontroversia de haeretioorum baptismo inter 1psum et stephanum episcopum Romanum exorta, a semetipso dissidens primatum negaverit nec ne"? jest J.Hellmann, "Seminaril theologiae catholicae socius". Owoc swoich poszukiwaí wyraz1ł we wniosku: "Quamvis Cyprianus, oontroversia de haereticorum baptismo inter ipsum et episcopum Romanum exorta, animi ardore abreptus acerbe graviterque Stephanum perstringeret, tamen primatum 1 psum el nequaquam abiudicavit, sed id solum vituperavit, quod illa potestate sibi una cum primatu data, abusus esset".

Druga zaś rozprawa o sygnaturze 408, napisana równiez po racin1e w 1872 r. o objętośc1 186 stron, nos1 tytuł: "S.Cyprian1 doctrina de catholicae ecclesiae unitate ita explicetur, ut appareat primo, qualem huius unitatis naturam doceat, deinde quatenus de hac ipsa cum suae aetatis scriptoribus ecclesiasticis consentiat". Jej autor rozpoczyna swe wywody od motta: "Corde credimus ot ore confitemur unam ecclesian non haereticorum, sed sanctam fomanam catholicam et apostolicam, extra quam neminem salvari" a koriczy je wnioskiem ogólnym /s. 186/, że Kościół święty przez nadversarios non praeval1turos esse - pro certo sperare possimus". Historie Kościoła mykładal wówczas na trydziale Teologicznym ks. Józef Hubert Reinkens/1857$1870 /^{6}$.

5 B.Kumor, Historia Kościoła, cz.1: Starożytność chrześc1jańska, Lublin 1973, 14; J.Umińsk1; Historla Kośc1oła, Opole 1959, I, 31.

6 E.Kle1 neldam, dz.cyt. 168; Schomat1smus des Bisthums Breslau und seines Delegatur - Bezirks fur das Jahr 1867, s.18. 
Do zaginionych wreszc1e w $1945 \mathrm{r}$. prac konkursorych należy rozprawa pisana $\approx 1867 \mathrm{r}$. pt. "Carpocratianae sectae historia 1ta exponatur, ut quae sit differentia inter ipsius doctrinam de omnium bonorum communitate et 11 lam Christianorum vitae ac victus communionem, quae Apostolorum aetate floruit, intelifgatur".

Ks. Bp Wincenty Urban - Wroctaip

DISSERTATIONES PATRISTICAE IN FACULTATE THEOLOGICA UNIVERSITATIS VRATISLAVIENSIS SAECULO XIX CONSCRIPTAE /Summarium/

Hoc in articulo descriptae sunt quinque dissertationes studentium theologiae de rebus patristicis, praesertim S.Cypriani, in Universitate Vratislaviensi uti "opera praemil" saeculo XIX compositae. 